\title{
FIELD EVALUATION OF CONDE PROGENIES WITH EARLY HEADING DATE AND RESISTANCE TO BACTERIAL LEAF BLIGHT
}

\author{
Fatimah*, Joko Prasetiyono, Ahmad Dadang, Tasliah, Masumah \\ Indonesian Center for Agricultural Biotechnology and Genetic Resources Research and Development, \\ Indonesia.
}

\begin{abstract}
Heading date is one of key traits in rice adaptation to different environments. Rice with early maturity is very useful for increasing rice production extensively especially in Indonesia. The improvement of rice variety Conde for heading date and resistance to bacterial leaf blight (BLB) was developed through Marker Assisted Backcrossing approach (MAB). Xa7 derived from Conde as recipient parents for resistance to BLB and Hd2 gene derived from Nipponbare as a donor parent for heading date. The aim of this research was to evaluate the performance of heading date and agronomic traits of $85 \mathrm{BC}_{2} \mathrm{~F}_{4}$ lines in two field stations, Sukamandi (West Java) and Maros (South Sulawesi). Molecular analysis of Xa7 on chromosome 6 and $\mathrm{Hd} 2$ gene on chromosome 7 and agronomic performance was evaluated. Foreground analysis resulted $41 \%$ for $\mathrm{Xa}$ and $66.7 \%$ for $\mathrm{Hd} 2$ gene in homozygous condition. The majority of lines have similar heading date and yield with Conde and more resistance to bacterial leaf blight (BLB) than Conde. Six lines flowered earlier 5 days than Conde in Sukamandi and three lines flowered earlier 3 days in Maros. Twelve lines with flowered earlier than Conde, resistance to BLB and similar yield with Conde were selected for background analysis resulted $93 \%$ genome recovery. These lines would be further evaluated in preliminary yield trail for their stability.
\end{abstract}

Keywords: $H d 2$, Maros, Sukamandi, Tropical region, $\mathrm{Xa7}$

"Corresponding author:

Indonesian Center for Agricultural Biotechnology and Genetic Resources Research and Development (ICABIOGRAD), Jl. Tentara Pelajar No.3A Cimanggu, Bogor 16111.

Tel. +62-21-8754587, Fax. +62-21-87754588

E-mail. fatimahsuw@gmail.com

\section{Introduction}

Flowering time is closely related to the grain yield for crop atribute to maintain an appropriate balance between full use of resources and avoidance of environmental stresses such as high temperature, low temperature, and drought. Abiotic stresses can pose a serious threat to spikelet fertility and consequently induce yield loss (Zhang et al., 2019).

Furthermore, early maturity allows farmers to increase their cropping intensity from two to three cropping of rice per year in tropical regions. Breeding for high yielding rice varieties with early maturity is considered important to increase cropping indexes in the fully irrigated farm lands (Fatimah et al., 2014; Pramudyawardani et al., 2015).

Until now, a number of genes/QTLs involved in the photoperiodic flowering pathway/heading date have been identified and mapped in rice (Hori et al., 2016). Eighteen QTLs (Hd1-Hd18) were detected with the different populations (Liu et al., 2018). They derived from crosses between Nipponbare and Kasalath and between Koshihikari and Hayamasari, and most of the QTLs have been cloned (Matsubara, 2008, Lin, 2000, Yano, 2001, Shibaya 2016).

Hd2 derived from a cross between Nipponbare and Kasalath (Yano et al., 1997; Yamamoto et al., 1998) and confirmed as OsPRR37 gene (pseudo-response regulator gene) (Koo et al., 2013). Hd2 is allelic with Ghd7.1 (Yan et al., 2013) and through map based cloning approach it was confirmed that Ghd7.1 is the OsPRR37 gene, or Gao et al., (2014) reported Days to heading 7 (DTH7) and Zhang et al., (2016) detected qHD7.2, both of them encodes a pseudo-response regulator protein (OsPRR37).

Hd2/Ghd7.1/DTH7/OsPRR37/qHD7.2, or later named $\mathrm{Hd} 2$, was located in 
LOC_Os07g49460 putative gene of 96.3-kb region in chromosome 7 (MSU Rice Genome Annotation Project). It involved in regulating rice heading date that suppresses flowering under short day and long day conditions (Koo et al. 2013; Yan et al. 2013) and played important roles in the expansion of rice cultivation to temperate areas and rice adaptation from low to high latitudes (Koo et al., 2013).

Farmers prefer grows short duration rice cultivar than long duration of rice cultivars because its easier and more efficient in crop management and field practice. They will save more energy, including water, fertilizer and labor, when they grow in short duration (Ahadiyat et al., 2012).

BLB caused by Xanthomonas oryzae pv. oryzae $(X \circ o)$ is a disastrous disease in rice worldwide. Yield losses caused by Xoo can be as high as $50 \%$ in some areas of Asia (Adhikari et al., 1995). In Indonesia, Suparyono and Sudir (1992) reported that damage threshold due to BLB was ca. $20 \%$ at about two weeks before harvest. Above the threshold, each $10 \%$ increase in the BLB severity the yield losses increased by 5 to $7 \%$. The evaluation of disease resistance in early breeding generations of rice is important to develop varieties with better resistance and the selection of appropriate donor parents which show broad spectrum of resistance is important for the breeding program.

Conde, Indonesian rice varieties, was nationally released on 2002 as new lowland rice varieties. It derived from IR64, an existing popular variety, this variety is well accepted by farmers and consumers (Toenniessen, 2003; Jena \& Mackill, 2008). The improvement of Conde rice variety that containing $\mathrm{Xa}$ gene was transferred with $\mathrm{Hd} 2$ gene from Nipponbare for earliness heading date and productivity has already developed through Marker Assisted Backcrossing approach (MABc) (Fatimah et al., 2014; Fatimah et al., 2018). MABc is using markers to select for target loci (donor), minimize the length of the donor segment containing a target locus, and/or accelerate the recovery of the recurrent parent genome during backcrossing (Hospital, 2001).

The aim of this research was to evaluate the performance of heading date and agronomic traits of $\mathrm{BC}_{2} \mathrm{~F}_{4}$ lines with $\mathrm{Xa}$ and $\mathrm{Hd} 2$ gene in two field stations, Sukamandi, West Java
Province in Western Indonesia and Maros, South Sulawesi Province in Eastern Indonesia.

\section{Materials and Methods}

\section{Plant materials}

This study was carried out using $85 \mathrm{BC}_{2} \mathrm{~F}_{4}$ lines of backcross population and their parents Conde (resistance to bacterial leaf blight, $X a 7+X a 4$ gene, recipient) and Nipponbare (Hd2 gene, donor). Two Indonesian elite rice varieties Inpari 13 and Ciherang also included as check variety for productivity and IRBB7 containing $\mathrm{Xa} 7$ gene as resistant check.

\section{Molecular Analysis}

The foreground selection :PCR amplification was generated using Biorad Thermal Cycler PCR machine using SSR primer RM1362 (F:TGATCTAAACAGGCCCTTAG and R:CATCATCAAGACCACACAT C) and RM7601 (F: GCCTCGCTGTCGCTAATATC and R: CAGCCTCTCCTTGTGTTG TG) associated with the QTLs for Hd2 locus located on chromosome 7 at the genetic distance of $116.1 \mathrm{cM}$ and $116.6 \mathrm{cM}$ (Fujino and Sekiguchi, 2005; Fujino and Sekiguchi, 2008). SSR Primer RM20582 (F: AGAGCGTCGTCCTTCACCATCC and R: GGCCAATACGACGATACATTACACG) linked to $\mathrm{Xa} 7$ locus located on chromosome 6 at the genetic distance of $118,5 \mathrm{cM}$ (Chen et al., 2008). For the background selection: two hundred and fourty three polymorphic SSR primers distributed on 12 chromosomes (Fatimah et al., 2014) were used for background selection. Amplified products was separated by electrophoresis in $8 \%$ polyacrylamide gel (Dual Triple-Wide MiniVertical System, C.B.S. Scientific, CA, USA) and observed by ethidium bromide and photographed under ultraviolet light using the gel documentation system (BioRad).

\section{BLB Evaluation}

These varieties were first sown in plastic boxes. The seedling was transplanted into pot containing natural paddy soil. Rice plants were grown under greenhouse condition. The cultivation and management of the rice proceeded as usual. The parents and check (Conde, Nipponbare and IRBB7) were inoculated with 39 Indonesian $\mathrm{Xoo}$ isolates at seedling stage (40 days old). Three isolates 
(Xoo1110, Xoo1122 and Xoo1130) that showed different patterns of resistance between Nipponbare (susceptible) and Conde or IRBB7 (resistant) continued for disease evaluation in the $\mathrm{BC}_{2} \mathrm{~F}_{4}$ population.

The fully expanded leaves were clipinoculated (Kauffman et al., 1973) with scissors, which were dipped, prior to inoculation, into a bacterial cell suspension containing approximately $10^{9} \mathrm{cfu} \mathrm{ml}^{-1}$. The suspension was prepared from 48-h old actively growing cultures of each isolate grown on NB medium. The length of the lesion was measured at 14 days after inoculation. The resistance reaction was classified into susceptible and resistant was based on the BLB intensity of Conde as the cut off. The resistant lines gave similar BLB intensity with Conde and susceptible lines gave higher BLB intensity than Conde.

\section{Field Experiments}

Heading date and agronomic performance were evaluated in two locations, at Indonesian Center for Rice Research, Sukamandi, West Java Province and Indonesian Cereals Research Institute, Maros, South Sulawesi Province. All experiments were conducted during the months of March to July. The experiments were laid out following a Randomized Complete Block Design (RCBD) which the $85 \mathrm{BC}_{2} \mathrm{~F}_{4}$ lines as treatment with three replications. The seeds of improved lines and checks were sown in a seed bed nursery. Two weeks-old seedlings were then manually transplanted into the rice field with one seedling planted per hill. The plot size was 1.5 $\mathrm{m} \times 2 \mathrm{~m}$. Each plot had a planting density of $25 \mathrm{~cm}$ between plants (within a row), and 25 $\mathrm{cm}$ between rows. In all experiments, fields were fertilized by hand broadcasting with 115 $\mathrm{kg} / \mathrm{ha}$ of urea, $38 \mathrm{~kg} / \mathrm{ha}$ of $\mathrm{P}_{2} \mathrm{O}_{5}$ and $50 \mathrm{~kg} / \mathrm{ha}$ of $\mathrm{K}_{2} \mathrm{O}$. Weed control was performed using chemical herbicide and hand weeding. From each breeding lines, five individual plants were selected for characterization of their agronomic performance.

\section{Data Collection}

Traits measurement of the agronomic performance were heading date $(\mathrm{DH})$, plant height $(\mathrm{PH})$, numbers of tiller (NT), and grain yield (GY). DH was recorded when $80 \%$ of the individual plants in each plot flowered. $\mathrm{PH}$ and NT were measured at maturity stage. $\mathrm{PH}$ was measured from the soil surface to the tip of the panicle. NT was counted manually. To measure GY in each plot, only the inner rows were used in square $(1 \mathrm{~m} \mathrm{x} 1 \mathrm{~m})$ consisted of 16 clumps. Two border rows and the border plants of each row were discarded. GY of each plot was adjusted to $14 \%$ moisture content. The GY per plot was extrapolated to tons per hectare.

\section{Data Analysis}

The marker data were scored as "A", "B" and " $\mathrm{H}$ " analyzed as homozygous recipient allele, homozygous dominant allele and heterozygous allele respectively. The marker data was analyzed using the software Graphical Genotyper (GGT 3.2) (Berloo, 2008). All agronomic traits in each experiment were subjected to statistical analysis using the SPSS v.17 program. Analysis of variance (ANOVA) was calculated based on the randomized complete block design (RCBD). A combined analysis of variance was performed using the mean value of data in all traits of each experiment. Duncan significant difference (DMRT) was determined at a five percent probability level to make the comparison between the mean values of each breeding line and parents.

\section{Results}

\section{Molecular Analysis}

Foreground analysis of the $85 \mathrm{BC}_{2} \mathrm{~F}_{4}$ lines revealed 56 lines $(66.7 \%)$ were homozygous to Nipponbare for the marker RM7601 and RM1362 linked to Hd2 and 35 lines (41\%) were homozygous to Conde for the marker RM20582 for Xa7 detection (Figure 1). Based on molecular data of $\mathrm{Xa7}$ and $\mathrm{Hd} 2$ gene, heading date and grain yield of $85 \mathrm{BC}_{2} \mathrm{~F}_{4}$ lines, it was selected 26 lines that homozygous to $\mathrm{Xa} 7$ and $\mathrm{Hd} 2$ gene, flowered earlier and gave similar yield with Conde variety.

The background analysis was conducted on 12 selected lines that flowered earlier, resistance to BLB and similar yield with Conde. It resulted the average of genome recovery of the selected $\mathrm{BC}_{2} \mathrm{~F}_{4}$ progenies in 12 chromosomes with the value was $93 \%$ (Figure 2). 


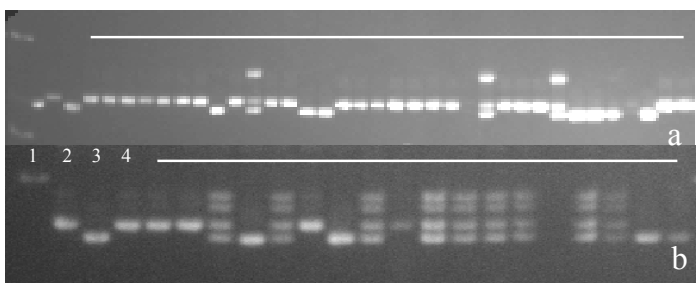

Figure 1. Foreground selection of $\mathrm{BC}_{2} \mathrm{~F}_{4}$ individues (Conde/Nipponbare) using marker a) RM7601 and b) RM20582. From left to right, lane 1: $100 \mathrm{bp}$ marker, lane 2: Conde, lane 3: Nipponbare, lane 4: $\mathrm{BC}_{2} \mathrm{~F}_{4}$ individues on $8 \%$ polyacrilamid gel electrophoresis.

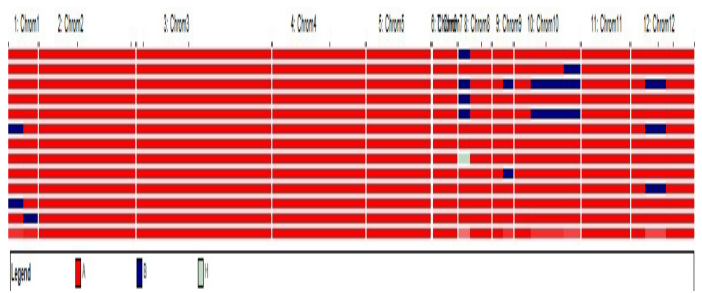

Figure 2. The background selection of the selected $\mathrm{BC}_{2} \mathrm{~F}_{4}$ lines using $243 \mathrm{SSR}$ primers distributed on 12 chromosomes.

\section{BLB Evaluation}

Conde, Nipponbare and IRBB7 were inoculated with 39 Indonesian Xoo isolates at seedling stage (40 days old). Conde was resistant to 39 isolates whereas IRBB7 was resistant to 24 isolates and Nipponbare was resistant to 23 isolates. Out of 39, 10 isolates showed the different patterns of resistance between Nipponbare (susceptible) and Conde/IRBB7 (resistance) (data not shown). This result indicated that resistance gene possessing by Nipponbare and Conde/IRBB7 were different genes and their resistant reaction were difference while Conde and IRBB7 giving the same reaction pattern against Indonesian $\mathrm{Xoo}$ isolates.

The resistance of Conde to bacterial blight within 14 days after inoculation (DAI) was evaluated with three selected Xoo strains, Xoo1110, Xoo1122, and Xoo1130 (Figure 3). Nipponbare was susceptible to the three Xoo strains. The BLB intensity of Conde were 4\% (Xoo1110), 5,38\% (Xoo1122) and 9.5\% (Xoo1130). The number of resistant $\mathrm{BC}_{2} \mathrm{~F}_{4}$ lines were $42 \%(\chi 2=1.98, p=0.16)$ with the $\mathrm{BLB}$ intensity of the $\mathrm{BC}_{2} \mathrm{~F}_{4}$ lines were lower than Conde $(<4 \%)$ (Figure 4$)$.

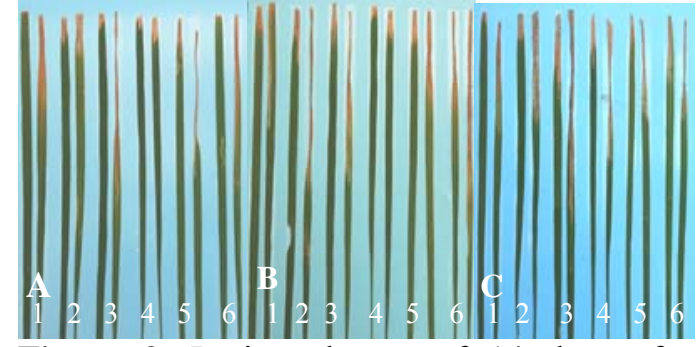

Figure 3. Lesions leaves of 14 days after inoculated with (A) Xoo1110, (B) Xoo1122, (C) Xoo1130. From left to right, line 1) IRBB7, 2) \#12, 3) \#01, 4) \#04, 5) \#05, and 6) Conde.

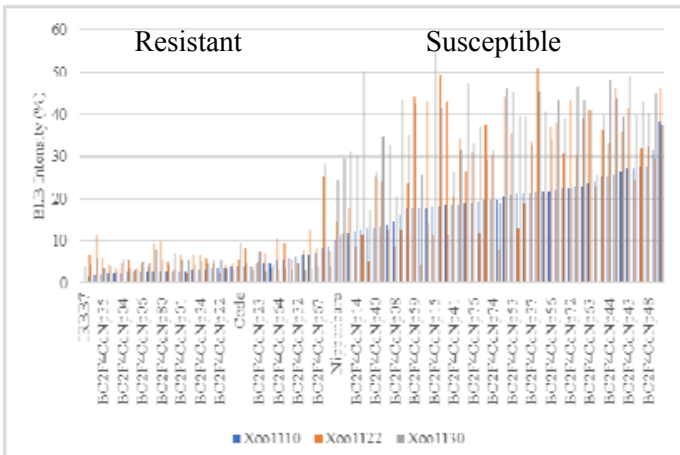

Figure 4. Distribution of BLB intensity (\%) after inoculation with Indonesian Xoo1110, Xoo1122, and Xoo1130 containing 85 individuals from a $\mathrm{BC}_{2} \mathrm{~F}_{4}$ population.

\section{Field Experiment}

Maros is located in eastern part of Indonesia $\left(40^{\circ} 45^{\prime}-50^{\circ} 07^{\prime}\right.$ South Latitude and $109^{\circ} 205^{\prime}-129^{\circ} 12^{\prime}$ East longitude) while Sukamandi located in western part of Indonesia (60 11' - 60 49' South Latitude and $107031^{\prime}$ - 1070 54' East longitude) that lead to some different climate parameter. Both field stations were located in the same altitude. Sukamandi in West Java Province was $16 \mathrm{~m}$ above sea level in Western Indonesia and Maros in South Sulawesi Province was $15 \mathrm{~m}$ above sea level in Eastern Indonesia (Figure 5). 


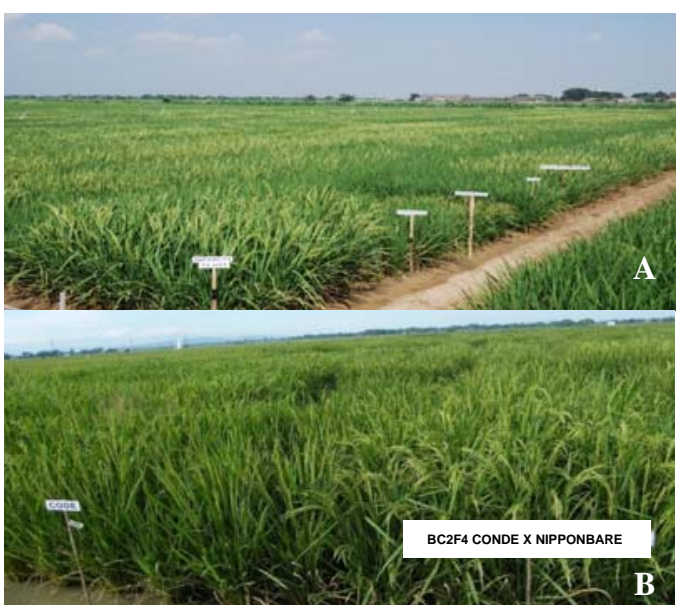

Figure 5. Agronomic Performance of $\mathrm{BC}_{2} \mathrm{~F}_{4}$ Plants in field, A) Sukamandi B) Maros.

The amount of rainfall and temperature of the field station in Sukamandi and Maros during the experiment (March - July 2012) (BMKG, 2012; BPS, 2013) is shown in Table 1. During the experimental trial, the climate of Maros categorized as wet tropical climate than Sukamandi, with an average rainfall of about $216 \mathrm{~mm}$ per month compare to Sukamandi 82 $\mathrm{mm}$ per month and the average temperature in Maros was $26,2{ }^{\circ} \mathrm{C}-27,4{ }^{\circ} \mathrm{C}$ compare to Sukamandi was $23^{\circ} \mathrm{C}-27,4^{\circ} \mathrm{C}$.

Table 1. Temperature and rainfall during experiment in Sukamandi and Maros field station.

\begin{tabular}{lllllllll}
\hline \multirow{3}{*}{ Month } & \multicolumn{2}{c}{ Rainfall $(\mathrm{mm})$} & \multicolumn{6}{c}{ Temperature $\left({ }^{\circ} \mathrm{C}\right)$} \\
\cline { 2 - 9 } & Suka & Maros & \multicolumn{5}{c}{ Sukamandi } & \multicolumn{3}{c}{ Maros } \\
\cline { 2 - 9 } & mandi & & min & $\max$ & av. & $\min$ & $\max$ & av. \\
\hline March & 175,2 & 574 & 22.8 & 29,5 & 23 & 24,3 & 30,3 & 26,3 \\
April & 138,2 & 230 & 24,5 & 31,6 & 27,4 & 24,1 & 31,4 & 27,4 \\
May & 7.0 & 164 & 22.8 & 31,5 & 23 & 24,6 & 31 & 27,2 \\
June & 14,4 & 69 & 22.5 & 31,2 & 23 & 23,8 & 31 & 26,7 \\
July & 0,2 & 44 & 21,9 & 32,8 & 26,5 & 23,0 & 30,6 & 26,2 \\
\hline
\end{tabular}

Table 2. The ANOVA of four traits in Conde/Nipponbare $\quad \mathrm{BC}_{2} \mathrm{~F}_{4}$ population

\begin{tabular}{llllll}
\hline Location & Trait & MS & F & P & CV (\%) \\
\hline Maros & Heading date & $15.72^{*}$ & 4.38 & 0 & 1.9 \\
& Tiller number & $33.46^{*}$ & 1.94 & 0.002 & 11.6 \\
& Plant Height & $461.36^{*}$ & 11.31 & 0 & 10.0 \\
& Grain Yield & $4.40^{*}$ & 1.66 & 0.005 & 31.2 \\
Suka & & & & & \\
mandi & Heading date & $23.94^{*}$ & 6.11 & 0 & 2.82 \\
& Tiller number & $17.77^{*}$ & 2.95 & 0 & 10.80 \\
& Plant Height & $653.82^{*}$ & 35.23 & 0 & 13.21 \\
& Grain Yield & $2.77^{*}$ & 2.88 & 0 & 17.11 \\
\hline
\end{tabular}

*:Significantly different at $5 \%$ level of Duncan significant difference.

MS: Mean square, F: FStat, P: Pvalue, CV: Coefficient of variation

\section{Agronomic and yield performance}

Analysis of variance (ANOVA) of four traits is presented in Table 2. In $\mathrm{BC}_{2} \mathrm{~F}_{4}$ population showed significant effects $(\mathrm{P}<0.05)$ were detected for all traits among the breeding lines at both Sukamandi and Maros field station. The agronomic performance of parents, check varieties and $\mathrm{BC}_{2} \mathrm{~F}_{4}$ lines from both field station is presented in Table 3 .

Table 3. Agronomic performance of parents, check varieties and $\mathrm{BC}_{2} \mathrm{~F}_{4}$ lines.

\begin{tabular}{lcccc}
\hline & $\begin{array}{c}\text { Heading } \\
\text { date } \\
\text { Variety/line }\end{array}$ & $\begin{array}{c}\text { Number } \\
\text { of Tiller }\end{array}$ & $\begin{array}{c}\text { Plant } \\
\text { Height } \\
(\mathrm{cm})\end{array}$ & $\begin{array}{c}\text { Yield } \\
(\text { Ton/ha) }\end{array}$ \\
\hline Nipponbare & 61 & 18 & 68 & 1.12 \\
Conde & 77 & 20 & 95 & 4.75 \\
Ciherang & 78 & 36 & 97 & 5.62 \\
Inpari 13 & 76 & 30 & 111 & 5.16 \\
$\mathrm{BC}_{2} \mathrm{~F}_{4}$ & 76 & 22 & 104 & 4.61 \\
Range of $\mathrm{BC}_{2} \mathrm{~F}_{4}$ & $73-83$ & $16-36$ & $79-133$ & $1.1-7.7$ \\
\hline
\end{tabular}

\section{Heading date}

The comparation between parents, progenies and other varieties revealed that Nipponbare, as the donor parent, was the earliest flowering (61 days after sowing/DAS), followed by $\mathrm{BC}_{2} \mathrm{~F}_{4}$ lines (73-76 DAS), Inpari 13 (76 DAS), Conde (77 DAS), and Ciherang (78 DAS) (Table 3).

In both field station, significant difference was found for heading date when comparison was made among the $\mathrm{BC}_{2} \mathrm{~F}_{4}$ lines and between $\mathrm{BC}_{2} \mathrm{~F}_{4}$ lines and Conde. In Sukamandi, the mean values of $\mathrm{BC}_{2} \mathrm{~F}_{4}$ lines ranged from 73 to 83 DAS, Nipponbare was 60 DAS and Conde was 78 DAS while in Maros ranged from 73 to 81 DAS, Nipponbare was 63 DAS and Conde was 76 DAS (Table 3 ).

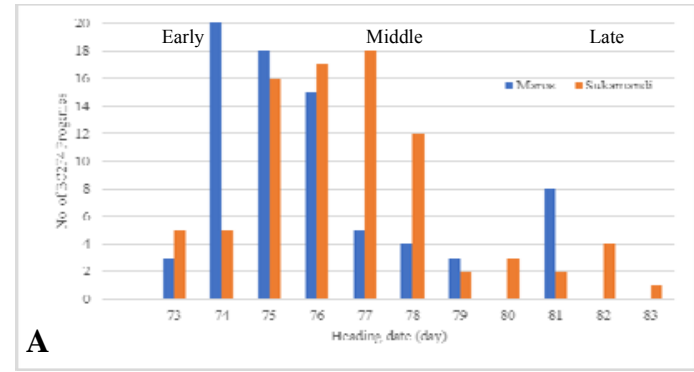




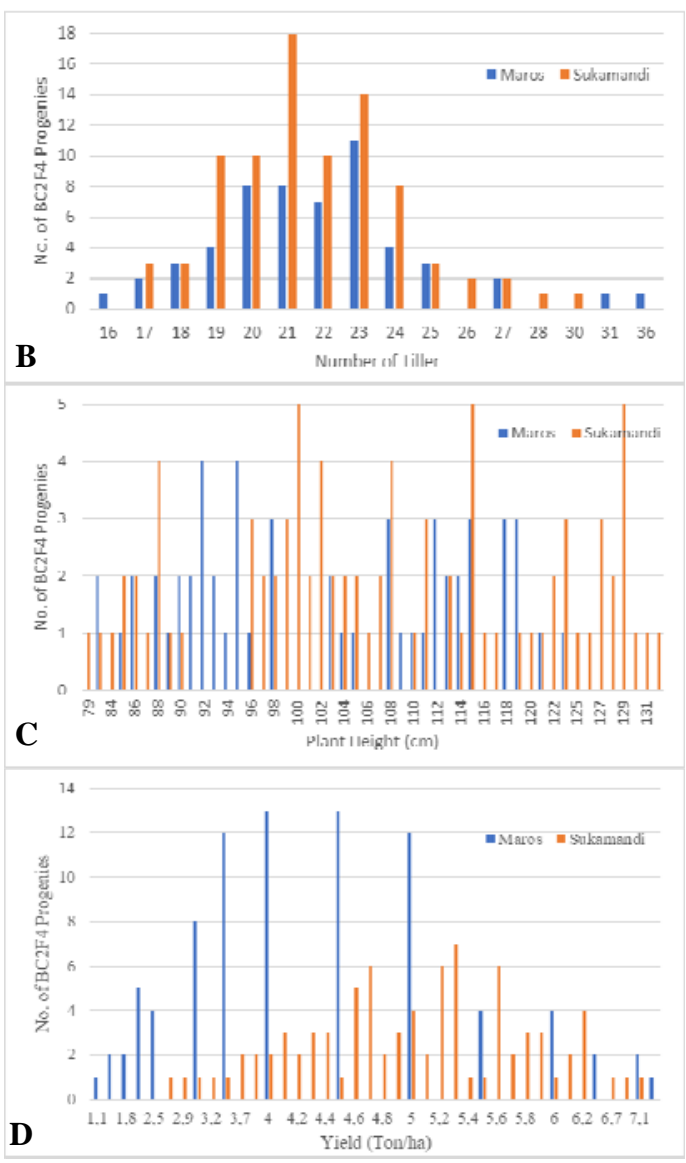

Figure 6. Distribution of agronomic trait on $\mathrm{BC}_{2} \mathrm{~F}_{4}$ population and parents for $\mathrm{A}$ ) heading date, B) tiller number, C) plant height and D) grain yield in Sukamandi and Maros field station.

The majority of the $\mathrm{BC}_{2} \mathrm{~F}_{4}$ lines in Sukamandi and Maros have similar heading date with Conde (not with Nipponbare) however it was found three different type of heading date. In Sukamandi: early-fixed ranged 73-74 DAS $(11,8 \%)$, middle-fixed ranged $75-79$ DAS $(77,6 \%)$ and late-fixed ranged $80-83$ DAS $(10,6 \%)$ while in Maros: early-fixed 73 DAS $(3,5 \%)$, middle-fixed ranged $74-79$ DAS $(87 \%)$ and late-fixed 81 DAS (9,4\%) (Figure 5). In Sukamandi, the $\mathrm{BC}_{2} \mathrm{~F}_{4}$ lines flowered earlier 5 days than Conde were line number \#31, \#43, \#44, \#45, \#48, and \#49 and in Maros, the $\mathrm{BC}_{2} \mathrm{~F}_{4}$ lines flowered earlier 3 days than Conde were \#09, \#72, \#74 (Figure 6).

Genotype variances were found for number of tiller among the $\mathrm{BC}_{2} \mathrm{~F}_{4}$ lines and Conde. The mean value of $\mathrm{BC}_{2} \mathrm{~F}_{4}$ lines was 17-30 in Sukamandi and 16-34 in Maros while Conde was 20 . The majority of $\mathrm{BC}_{2} \mathrm{~F}_{4}$ lines have similar number of tiller with Conde was $81 \%$ in Sukamandi and 43,5\% in Maros (Figure 6). Line number \#28, \#30, \#31, \#33, \#78, \#83, $\# 84$, and \#85 (Sukamandi) and \#04, \#15, and \#26 (Maros) gave higher number of tiller than Conde.

Genotype variances were found for plant height among the $\mathrm{BC}_{2} \mathrm{~F}_{4}$ lines and Conde. The mean value of plant height of $\mathrm{BC}_{2} \mathrm{~F}_{4}$ lines ranged from 100 to $133 \mathrm{~cm}$ in Sukamandi and 82 to $124 \mathrm{~cm}$ in Maros while Conde was $91 \mathrm{~cm}$ in Maros and $100 \mathrm{~cm}$ in Sukamandi (Figure 6). The majority of $\mathrm{BC}_{2} \mathrm{~F}_{4}$ lines have similar plant height with Conde was $72 \%$ in Sukamandi and $53 \%$ in Maros (Figure 6).

There is no significant difference of grain yield observed in Sukamandi among the $\mathrm{BC}_{2} \mathrm{~F}_{4}$ lines and Conde. The mean value of grain yield of the breeding line ranged from 2.5 to 7.0 ton/ha while Conde was 6,5 ton/ha (Figure $6)$. The majority of $\mathrm{BC}_{2} \mathrm{~F}_{4}$ lines have similar yield with Conde $(74,2 \%)$. Line number $\# 03$, $\# 9$, and \#78 were giving higher yield than Conde and resistant to BLB however the heading date of these lines was similar with Conde (77 DAS).

Significance differences of grain yield observed in Maros among $\mathrm{BC}_{2} \mathrm{~F}_{4}$ lines and Conde. The mean value of grain yield of the breeding line ranged from 1.1 to 7.7 ton/ha while Conde was 2.8 ton/ha (Figure 6). The majority of the breeding lines have similar yield with Conde $(83,5 \%)$. Line number $\# 01$, $\# 05$, and \#06 were flowered earlier than Conde, resistance to BLB and higher yield than Conde.

\section{Correlation analysis}

Based on their correlation using Pearson correlation analysis showed that there is a low correlation on $\mathrm{BC}_{2} \mathrm{~F}_{4}$ lines between heading date and tiller number however both of them are statistically significant. Low correlation also revealed between heading date and plant height however it was not significant. The low correlation also showed between heading date and yield however both of them are statistically significant. The low correlation also showed between heading date and resistance to bacterial leaf blight however it was not significant (Table 4).

\section{Breeding Selection}

The $\mathrm{BC}_{2} \mathrm{~F}_{4}$ lines were selected based on the molecular analysis in foreground selection that 
homozygous to Conde for $\mathrm{Xa} 7$ and homozygous to Nipponbare for $\mathrm{Hd} 2$ gene, and background selection with genome recovery higher than $84 \%$, early heading date, resistance to bacterial leaf blight, and similar or higher yield than Conde, then it was selected 16 $\mathrm{BC}_{2} \mathrm{~F}_{4}$ lines for further evaluation in preliminary yield trail for their stability (Table 5).

Tabel 4. Coeficient of Pearson Correlation.

\begin{tabular}{|c|c|c|c|c|}
\hline Maros & Parameter & $\begin{array}{c}\text { Heading } \\
\text { date }\end{array}$ & $\begin{array}{c}\text { Plant } \\
\text { Height }\end{array}$ & $\begin{array}{l}\text { No.of } \\
\text { tiller }\end{array}$ \\
\hline Pearson & Heading date & 1 & 0,141 & 0,256 \\
\hline \multirow[t]{2}{*}{ Correlation } & Plant Height & 0,141 & 1 & $-0,192$ \\
\hline & No.of tiller & 0,256 & $-0,192$ & 1 \\
\hline \multirow{3}{*}{$\begin{array}{l}\text { Sig. (1- } \\
\text { tailed) }\end{array}$} & Heading date & & 0,009 & 0 \\
\hline & Plant Height & 0,009 & & 0,001 \\
\hline & No.of tiller & 0 & 0,001 & \\
\hline Sukamandi & Parameter & $\begin{array}{c}\text { Heading } \\
\text { date }\end{array}$ & $\begin{array}{c}\text { Plant } \\
\text { Height }\end{array}$ & $\begin{array}{l}\text { No.of } \\
\text { tiller }\end{array}$ \\
\hline Pearson & Heading date & 1 & $-0,014$ & 0,325 \\
\hline \multirow[t]{2}{*}{ Correlation } & Plant Height & $-0,014$ & 1 & $-0,28$ \\
\hline & No.of tiller & 0,325 & $-0,28$ & 1 \\
\hline \multirow{3}{*}{$\begin{array}{l}\text { Sig. (1- } \\
\text { tailed) }\end{array}$} & Heading date & & 0,384 & 0 \\
\hline & Plant Height & 0,384 & . & 0 \\
\hline & No.of tiller & 0 & 0 & 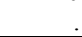 \\
\hline Greenhouse & Parameter & $\begin{array}{c}\text { Heading } \\
\text { date }\end{array}$ & $\begin{array}{c}\text { BLB } \\
\text { Intensity }\end{array}$ & \\
\hline Pearson & Heading date & 1 & $-0,119$ & \\
\hline Correlation & BLB Intensity & $-0,119$ & 1 & \\
\hline Sig. (1- & Heading date & ( & 0,128 & \\
\hline tailed) & BLB Intensity & 0,128 & s. & \\
\hline
\end{tabular}

Tabel 5. Agronomy performance of the selected $\mathrm{BC}_{2} \mathrm{~F}_{4}$ of Conde in Sukamandi (S) and Maros (M) field station.

\begin{tabular}{|c|c|c|c|c|c|c|c|c|c|}
\hline No. & Lines & \multicolumn{2}{|c|}{ Hd } & NT & PH & Yield & \multicolumn{2}{|c|}{ BLB } & GR \\
\hline 1 & $\# 01$ & $74 *$ & $E$ & 22 & 95 & 5,64 & 5,10 & $\mathrm{R}$ & 97 \\
\hline 2 & \#02 & $74 *$ & E & 23 & 93 & 5,43 & 3,85 & $\mathrm{R}$ & 97 \\
\hline 3 & \#03 & 76 & M & 23 & 97 & 5,42 & 4,48 & $\mathrm{R}$ & 84 \\
\hline 4 & $\# 05$ & 75 & $\mathrm{E}$ & 23 & 96 & $6,13^{*}$ & 3,78 & $\mathrm{R}$ & - \\
\hline 5 & $\# 07$ & 75 & E & 22 & 97 & 4,23 & 4,08 & $\mathrm{R}$ & 85 \\
\hline 6 & \#22 & 78 & M & 23 & 87 & 5,06 & 3,81 & $\mathrm{R}$ & 84 \\
\hline 7 & \#23 & $74 *$ & $\mathrm{E}$ & $25^{*}$ & 84 & 4,36 & 5,78 & $\mathrm{R}$ & 95 \\
\hline 8 & \#24 & 78 & M & 22 & 88 & 3,84 & 3,63 & $\mathrm{R}$ & - \\
\hline 9 & \#26 & 75 & E & $24 *$ & 83 & 5,2 & 4,28 & $\mathrm{R}$ & 95 \\
\hline 10 & \#31 & $74 *$ & $\mathrm{E}$ & $27 *$ & 103 & 2,57 & 5,02 & $\mathrm{R}$ & 97 \\
\hline 11 & \#32 & $75^{*}$ & $\mathrm{E}$ & $24 *$ & 86 & 3 & 5,32 & $\mathrm{R}$ & 95 \\
\hline 12 & \#35 & 81 & $\mathrm{~L}$ & 22 & $113^{*}$ & 3,72 & 3,79 & $\mathrm{R}$ & - \\
\hline 13 & $\# 65$ & 75 & $\mathrm{E}$ & 23 & $117 *$ & 4,76 & 6,59 & $\mathrm{R}$ & 97 \\
\hline 14 & \#68 & 75 & $\mathrm{E}$ & 23 & $122 *$ & 5,35 & 5,03 & $\mathrm{R}$ & 95 \\
\hline 15 & \#78 & 76 & M & 19 & 108 & $6,45^{*}$ & 5,67 & $\mathrm{R}$ & 95 \\
\hline 16 & $\# 79$ & 78 & $\mathrm{~L}$ & 22 & 92 & 4,58 & 6,66 & $\mathrm{R}$ & - \\
\hline & onbare & 61 & $E$ & 17 & 68 & 1,08 & 16,84 & $\mathrm{~S}$ & \\
\hline & Conde & 77 & M & 20 & 95,5 & 4,68 & 15,39 & $\mathrm{~S}$ & \\
\hline & pari 13 & 73 & $\mathrm{E}$ & 30 & 111 & 5,16 & - & $\mathrm{S}$ & \\
\hline & herang & 76 & $\mathrm{M}$ & 36 & 97 & 5,62 & - & $\mathrm{S}$ & \\
\hline
\end{tabular}

*Significantly different at $5 \%$ level of Duncan significant difference.

Hd: Heading date (DAS), E; Early, M: Middle, L: Late, NT: Number of tillers, PH: Plant Height $(\mathrm{cm})$, Yield: ton/ha, BLB: BLB Intensity (\%), R: Resistant, S: Susceptible, GR: Genome Recovery (\%).

\section{Discussion}

Rice heading date is one of the most important agronomic traits for season adaptation and grain yield, which is affected by both genetic and environmental factors (Ebana et al. 2011). Rice is a facultative shortday (SD) plant whose flowering is accelerated under SD conditions ( $<10$-h light/day) and is delayed under longday (LD) conditions ( $>14$-h light/day) (Izawa, 2007; Tsuji et al., 2008). In tropical regions, the daylength is less than 13.5 $\mathrm{h}$, and the daily temperature is high, which ensures that rice can grow all year (Liu et al., 2018).

Nipponbare is a japonica rice variety with photoperiod-sensitive identified $\mathrm{Hd} 2$ and $\mathrm{Hd} 4$ gene (Yano et al., 1997) used as donor in this study while Conde is an indica rice variety and an elite cultivar used as recipient parent. Many heading-date quantitative trait locus ( $\mathrm{Hd}$ QTLs) (Hd1- Hd3a, Hd3b-Hd17) were found in the crosses of japonica and indica cultivars with distinct heading dates and photoperiod sensitivity (Yano et al., 2001; Monna et al., 2002; Uga et al., 2007). Yano et al. (1997) indicated that five QTL (Hd1-Hd5) cause variation in rice heading date in crosses between Nipponbare and Kasalath. Koo et al. (2013) demonstrate that natural variation in PRR37/Ghd7/Hd2 has contributed to japonica rice adaptation to growth in the northernmost regions of rice cultivation as well as double cropping of an indica variety in low-latitude regions (tropical region) by reducing days to heading and photoperiod sensitivity.

In this study, it was found three different phenotype of heading date of $\mathrm{Hd} 2$ gene in $\mathrm{BC}_{2} \mathrm{~F}_{4}$ lines. Six lines flowered earlier 5 days than Conde in Sukamandi and three lines flowered earlier 3 days in Maros. In line with Prasetiyono et al. (2014) reported that the earliest flowering line in the improved Ciherang was 4 days earlier than Ciherang. Yamamoto et al. (1998) reported that large variation in days to heading of $H d 2$ was observed in the population of crossing between Nipponbare and Kasalath. Zhang et al. (2019) mentioned the genetic interactions among Ghd7, Ghd8, OsPRR37/Hd2 and Hd1 contribute to large variation in heading date in rice.

Grain yield is positively correlated with heading date, especially in low latitude areas (tropical region) where the temperature is 
warm year-round (Gao et al. 2014; Li et al. 2018). In this study, in Maros, the average minimum air temperature was $24^{\circ} \mathrm{C}$ and average maximum air temperature was $30,8^{\circ} \mathrm{C}$ while in Sukamandi, the average minimum air temperature was $23,2^{\circ} \mathrm{C}$ and average maximum air temperature was $31,3^{\circ} \mathrm{C}$. It was reported that $\mathrm{Hd} 2$ is not only photoperiodrelated, but also a temperature-related QTL (Nakagawa et al., 2005). Under low temperature in long day conditions it delays heading (Song et al., 2012).

In this study also showed that the majority of $\mathrm{BC}_{2} \mathrm{~F}_{4}$ lines had heading date and yield similar to Conde and well adapted to different part of Indonesia. This also maintained the yield potential and stability of the Conde across two experimental locations in Indonesia with little difference among both locations. Yan et al. (2013) mentioned that Hd2 contributes greatly to regulating rice photoperiodic flowering, plant architecture and grain productivity and provides an opportunity to breed high-yield varieties with improved adaptive flexibility for special farming regions.

The use of resistant cultivars is the most economical and effective way to control BLB disease and has played a key role in sustaining rice productivity that requires no additional cost to farmers and is environmentally safe. Fatimah et al. (2018) reported that Conde revealed the similar gene action with $\mathrm{Xa}$ gene for BLB that exhibits high resistance to most of the Indonesian races of (BLB). In this study, the majority of $\mathrm{BC}_{2} \mathrm{~F}_{4}$ lines gave more resistance to BLB than Conde.

This study provides a marked improvement of heading date and BLB resistance in Conde progenies. The preliminary yield trial needs to be done before amplifying seed for large-scale testing and validation in farmers fields at target areas. The result of this study contributes to enhancing and sustaining future livelihoods and food security in Indonesia versus climate change.

\section{Acknowledgements}

This work was financially supported by Incentive Research Program (PKPP) year 2012 of Ministry of Research and Technology.

\section{References}

Ahadiyat, Y.R., Hidayat, P., Mujiono, Tarjoko, \& Aguston, T. (2012). Harvest time and yield of traditional rice cultivars based on $\mathrm{N}$ and $\mathrm{P}$ fertilizer management. Research Journal of Pharmaceutical, Biological and Chemical Sciences 3(3):662-669.

Adhikari, T.B., Cruz, C.M.W., Zhang, Q., Nelson, R.J., Skinner, D.Z., Mew, T.W., Leach, J.E. (1995). Genetic diversity of Xanthomonas oryzae pv. oryzae in Asia. Appl Environ Microbiol 61:966-971.

Berloo, R.V. (2008). GGT 2.0: Versatile software for visualization and analysis of genetic data. Journal of Heredity, 99: 232-236.

BMKG. (2012). Buletin Analisis Hujan dan Indeks Kekeringan Bulan April 2012 dan Prakiraan Hujan Bulan Juni, Juli dan Agustus 2012. p 31.

BPS Maros. (2013). Maros dalam angka 2013. Badan Pusat Satatistik Kabupaten Maros. Seksi Integrasi Pengolahan Data dan Diseminasi Statistik. $p 212$.

Chen, S., Huang, Z., Zeng, L., Yang, J., Liu, Q., \& Zhu, X. (2008). High-resolution mapping and gene prediction of Xanthomonas Oryzae pv. oryzae resistance gene Xa7. Mol Breeding, 22:433-441.

Ebana, K., Shibaya, T., Wu, J., Matsubara, K., Kanamori, H., Yamane, H., Yamanouchi, U., Mizubayashi, T., Kono, I., Shomura, A., Ito, S., Ando, T., Hori, K., Matsumoto, T., \& Yano, M. (2011). Uncovering of major genetic factors generating naturally occurring variation in heading date among Asian rice cultivars. Theor Appl Genet, 122: 1199-1210.

Fatimah, Prasetiyono, J., Dadang, A. \& Tasliah. (2014). Improvement of early maturity in rice variety by marker assisted backcross breeding of Hd2 gene. Indonesian Journal of Agricultural Science, 15(2):55-64.

Fatimah, Prasetiyono, J., Polosoro, A., \& Baroya, M. (2018). Molecular detection of resistance to bacterial leaf blight on Conde indonesian rice variety. Annales Bogorienses, 22(1):27-34.

Fujino, K., \& Sekiguchi, H. (2005). Mapping of QTLs conferring extremely early heading in rice (Oryza sativa L.). Theor. Appl. Genet. 111: 393398.

Fujino, K., \& Sekiguchi, H. (2008). Mapping of quantitative trait loci controlling heading date among rice cultivars in the northernmost region fo Japan. Breeding Science, 58:367-373.

Gao, H., Jin, M., Zheng, X., Chen, J., Yuan, D., Xin, Y., Wang, M., Huang, D., Zhang, Z., Zhou, K., Sheng, P., Ma, J., Ma, W., Deng, H., Jiang, S. Liu, H. Wang, C. Wu, L. Yuan, J., \& Wan, L. (2014). Days to heading 7, a major quantitative locus determining photoperiod sensitivity and 
regional adaptation in rice. Proc. Natl. Acad. Sci., 111:16337-16342.

Hospital, F. (2001). Size of donor chromosome segments around introgressed loci and reduction of linkage drag in marker assisted backcross programs. Genetics, 158: 1363-1379.

Hori, K., Matsubara, K., \& Yano, M. (2016). Genetic control of flowering time in rice: Integration of Mendelian genetics and genomics. Theor. Appl. Genet., 129:2241-2252.

Izawa, T. (2007). Adaptation of flowering-time by natural and artificial selection in Arabidopsis and rice. J. Exp. Bot. 58:3091-3097.

Jena, K.K., \& MacKill, D.J. (2008). Molecular markers and their use in marker-assisted selection in Rice. Crop Science, 48:1266-1276.

Kauffman, H.E., Reddy, A.P.K., Hsieh, S.P.Y., \& Merca, S.D. (1973). An improved technique for evaluating resistance of rice varieties to Xanthomonas oryzae pv. oryzae. Plant Diseases Rep, 57: 537-541.

Koo, B.H., Yoo, S.C., Park, J.W., Kwon, C.T., Lee, B.D., An, G., Zhang, Z., Li, J., Li, Z., \& Paek, N.C. (2013). Natural variation in OsPRR37 regulates heading date and contributes to rice cultivation at a wide range of latitudes. Molecular Plant, 6:1877-1888.

Li, F., Xie, J., Zhu, X. et al (2018). Genetic basis underlying correlations among growth duration and yield traits revealed by GWAS in Rice (Oryza sativa L.). Front Plant Sci. 9:650.

Lin, H., Yamamoto, T., Sasaki, T., \& Yano, M. (2000). Characterization and detection of epistatic interactions of 3 QTLs, Hd1, Hd2, and $\mathrm{Hd} 3$, controlling heading date in rice using nearly isogenic lines. Theor. Appl. Genet., 101:1021- 1028 .

Liu, H., Li, Q., \& Xing, Y. (2018). Genes Contributing to Domestication of Rice Seed Traits and Its Global Expansion Haiyang. Genes, 9: 489. doi:10.3390/genes9100489.

Matsubara, K., Kono, I., Hori, K., Nonoue, Y., Ono, N., Shomura, A., Mizubayashi, T., Yamamoto, S., Yamanouchi, U., Shirasawa, K., et al. (2008). Novel QTLs for photoperiodic flowering revealed by using reciprocal backcross inbred lines from crosses between japonica rice cultivars. Theor. Appl. Genet., 117: 935-945.

Monna, L., Lin, X., Kojima, S., Sasaki, T., \& Yano, M. (2002). Genetic dissection of a genomic region for a quantitative trait locus, $\mathrm{Hd} 3$, into two loci, $H d 3 a$ and $H d 3 b$, controlling heading date in rice. Theor. Appl. Genet. 104:772-778.

Nakagawa, H., Yamagishi, J., Miyamoto, N., Motoyama, M., Yano, M., \& Nemoto, K. (2005). Flowering response of rice to photoperiod and temperature: a QTL analysis using a phenological model. Theor. Appl. Genet. 110:778-786.
Pramudyawardani, E.F., Suprihatno, B., \& Mejaya, M.J. (2015). Potensi Hasil Galur Harapan Padi Sawah Ultra Genjah dan Sangat Genjah. Penelitian Pertanian Tanaman Pangan, 34(1):1-11.

Prasetiyono, J., Dadang, A., Ma'sumah, Tasliah, Fatimah, \& Silitonga, T.S. (2015). Evaluasi molekuler dan lapangan terhadap galur-galur padi berumur genjah dan produktivitas tinggi turunan Ciherang. Penelitian Pertanian Tanaman Pangan, 34(1):13-20.

Shibaya, T., Hori, K., Ogiso-Tanaka, E. Yamanouchi, U., Shu, K., Kitazawa, N., Shomura, A., Ando, T., Ebana, K., \& Wu, J. (2016). Hd18, encoding histone acetylase related to Arabidopsis flowering locus D, is involved in the control of flowering time in rice. Plant Cell Physiol., 57:1828-1838.

Song, Y.L., Gao, Z.C., and Luan, W.J. (2012). Interaction between temperature and photoperiod in regulation of flowering time in rice. Sci. China Life Sci. 55:241-249.

Suparyono and Sudir. (1992). Bacterial leaf blight disease progression at different growth stage and its effect on rice yield (in Indonesian). Media Penelitian Sukamandi 12: 6-9.

Toenniessen, G.H., O’Toole, J.C., \& DeVries, J. (2003). Advances in plant biotechnology and its adoption in developing countries. Current Opinion in Plant Biology, 6:191-198.

Tsuji, H., Tamaki, S., Komiya, R., \& Shimamoto, K. (2008). Florigen and the photoperiodic control of flowering in rice. Rice, 1: 25-35.

Uga, Y., Nonoue, Y., Liang, Z.W., Lin, H.X., Yamamoto, S., Yamanouchi, U., \& Yano, M. (2007). Accumulation of additive effects generates a strong photoperiod sensitivity in the extremely late-heading rice cultivar 'Nona Bokra'. Theor. Appl. Genet. 114:1457-1466.

Yamamoto T., Kuboki, Y., Lin, S.Y., Sasaki, T., \& Yano, M. (1998). Fine mapping of quantitative trait loci $H d-1, H d-2$ and $H d-3$, controlling heading date of rice, as single Mendelian factors. Theor Appl Genet., 97:37-44.

Yan, W., Liu, H., Zhou, X., et al. (2013) Natural variation in Ghd7.1 plays an important role in grain yield and adaptation in rice. Cell Res 23(7):969-971.

Yano, M., Harushima, Y., Nagamura Y., Kurata, N., Minobe, Y., Sasaki, T. (1997). Identification of quantitative trait loci controlling heading date in rice using a high-density lingkage map, Theor. Appl. Genet., 95:1025-1032.

Yano, M., Kojima, S., Takahashi, Y., Lin, H., \& Sasaki, T. (2001). Genetic control of flowering time in rice, a short-day plant. Plant Physiol. 127:1425-1429.

Zhang, Z.H., Cao, L.Y., Chen, J.Y., Zhang, Y.X., Zhuang, J.Y., \& Cheng, S.H. (2016). Effects of $H d 2$ in the presence of the photoperiod- 
insensitive functional allele of $\mathrm{Hd} 1$ in rice. Biology Open, 5: 1719-1726 doi:10.1242/bio.021071.

Zhang, Z.H., Zhu Y.J., Wang, S.L., Fan, Y.Y., \& Zhuang, J.Y. (2019). Importance of the
Interaction between Heading Date Genes Hd1 and Ghd7 for Controlling Yield Traits in Rice. Int. J. Mol. Sci. $20: 516$. doi:10.3390/ijms20030516. 